\title{
* BoTANur \\ Use of medicinal plants in traditional health care practices: A case study in Talwandi Sabo, Bathinda District, Punjab (India)
}

\author{
Kuljinder Kaur $^{1 *}$, Amandeep Kaur', Sweta Thakur ${ }^{2}$ \\ 'Department of Botany, Akal University, Talwandi Sabo, Bathinda, Punjab- 151302, India, '2Department of Agriculture, \\ Noida International University, Gautam Budh Nagar, Uttar Pradesh- 203201, India
}

Received: April 11, 2020 Revised: May 26, 2020 Accepted: May 31, 2020 Published: June 08, 2020

*Corresponding Author: Kuljinder Kaur Email: kuljinder_bot@auts. ac.in

\begin{abstract}
A comprehensive study was conducted to document the available medicinal plants and their traditional applications among the local people from July 2018 to June 2019 in Talwandi Sabo town of Bathinda District of Punjab. Purposive sampling method was used to select traditional medicinal practitioners of the study area. A semi-structured questionnaire was prepared and personal interviews were conducted to gather firsthand information about ethno-medicinal plants. Analysis of data revealed the use of 88 medicinal plant species belonging to 77 genera and 42 families for the treatment of about 60 ailments. The highest number of plants were used for gastrointestinal problems, skin problems followed by respiratory diseases, skeletomuscular diseases and dental problems. Traditional healers are still playing a great role in the primary health care system of Talwandi Sabo. Some practitioners were ensuring the $100 \%$ results of their formulations against many serious diseases. Further, the scientific validation of these formulations should be done for getting new alternative medicines against these diseases.
\end{abstract}

KEYWORDS: Bathinda, Ethnomedical, Medicinal plants, Talwandi Sabo, Traditional knowledge

\section{INTRODUCTION}

India is the country gifted with a great variety of vegetation among which most occurring plant species are medicinal plants. Medicinal plants are commonly used by tribal and rural people to cure minor ailments. According to WHO, majority of the people living in rural areas are dependent on medicinal plants for curing common diseases. The wide range of medicinal plants are wild and the traditional healers commonly purify the plants and prepare medicines. It is worthwhile to mention that before the availability of synthetic drug, people were completely dependent on traditional remedies for primary healthcare system. In the Indian context, these household remedies are better known as Ghrelu nuskhe (Home remedies). However due to modernization, transformation in cultural practices and development of allopathic systems of medicine, herbal medicines gradually lost its popularity among people.

Latterly herbal medicine has gained popularity due to drug resistance, unaffordable cost and many side effects of allopathic medicines. The efficacy of some herbal products is beyond doubt, e.g. Artemisia апnua (i.e. artemesinin: anticanceric), Silybum marianum (i.e., silymarin: effective in treating diseases of the liver) and Taxus brevifolia (i.e. taxols: used for treating refractory tumors) [1,2 and 3]. Medicinal plants are now more focused than ever because today's around $50 \%$ of synthetic drugs have roots in medicinal plants. Therefore, now there is an explosive growth of plant based herbal industries [4].

The traditional healers and old age people are commonly having more knowledge about these indigenous practices. Young generation has little interest in this valuable knowledge because of industrialization, urbanization and more use of synthetic drugs. This traditional knowledge has been transferred through oral communication within the society and from generation to generation in certain families without any written record [5]. After some decades there would be no one to tell us about the use of herbal plants in our daily life, as this traditional knowledge will vanish with the old people. Apart from this, ever-escalating threats to biodiversity and the intensifying biopiracy controversies, have necessitated an urgent documentation of the traditional uses of bioresources. So, it is very important to document the traditional knowledge and to generate awareness about its utmost significance in this age of excessive 
diseases, medication and side effects [6]. Traditional knowledge of medicinal plants and their use by indigenous cultures are not only useful for community healthcare and drug development but also for conservation of cultural traditions and biodiversity.

Recently, several steps have been taken by Indian government to conserve medicinal plants and their associated traditional knowledge. Medicinal plant boards have been constituted at state and center level to inspire farmers for adopting cultivation of medicinal plants. Herbal gardens have been developed to make the common man conversant with the rich heritage of Indian system of medicine [7]. National Biodiversity Authority (NBA) at central level, State Biodiversity Board (SBB) at state level and Biodiversity Management Committees (BMCs) at local level has been constituted under Biodiversity Act, 2002 to conserve biodiversity or its associated traditional knowledge. NBA has initiated the preparation of People Biodiversity Register (PBR) at local level to document local biological resources and its associated traditional knowledge. Hence the current study is a small step in this direction to document and preserve the plant based traditional medicines used by locals for healthcare and for sharing it with other communities through publish literature.

\section{MATERIALS AND METHODS}

\section{The Study Area}

The area selected for present study was Talwandi Sabo located in Bathinda district of Punjab. Bathinda is one of the largest districts of Punjab. Talwandi Sabo is the municipal council in this district. It lies between the coordinates of $29.988268^{\circ}$ North latitude to $75.078678^{\circ}$ East longitude (Figure 1). In 2011 this region consists of 13 wards but recently in 2018, the area is divided into 15 wards. It is one of the famous Takht among five Takhts of Sikhism known as Takht Sri Damdama Sahib. Total geographical area of Talwandi Sabo nagar panchayat is $17 \mathrm{~km}^{2}$. Although several workers have worked on the indigenous medical practices of aboriginal people, tribals and other folk healers of India using medicinal herbs, there are only a few works on medicinal plants used by natives of Punjab in traditional healthcare practices. After screening the available literature, it was found that no study on traditional medicinal plants was ever carried out in this region; hence this area was selected for the present investigation.

\section{Methodology}

The present study was carried out in Talwandi Sabo town of Bathinda district of Punjab. A comprehensive study was conducted to document the available medicinal plants and their traditional applications among the local people from July 2018 to June 2019. Purposive sampling method was used to select traditional medicinal practitioners of the study area. Ethno-medicinal data was collected from 25 knowledgeable informants or practitioners for this investigation. The informants were selected in such a way that all ward of the study area have been covered. A semistructured questionnaire was prepared and personal interviews were conducted to gather first-hand information about ethnomedicinal plants used for human and livestock ailments.

Usually, the survey was started with the interview of elderly and experienced members, locally known as Hakims or Vaids (Traditional healers). Often, they were accompanied to the field for the identification of plant species used and authentication of plant specimens collected from their wild habitats. Besides this, the accuracy of the curative features of these plants have also been proved by interviewing the common people of surveyed localities who themselves have used these plants for health treatments. Photographs of some locally available plants have been taken in their natural habitat.

\section{Data Interpretation}

The collected information was screened for number of plants used in medicinal purposes, their mode of preparation, part used, their

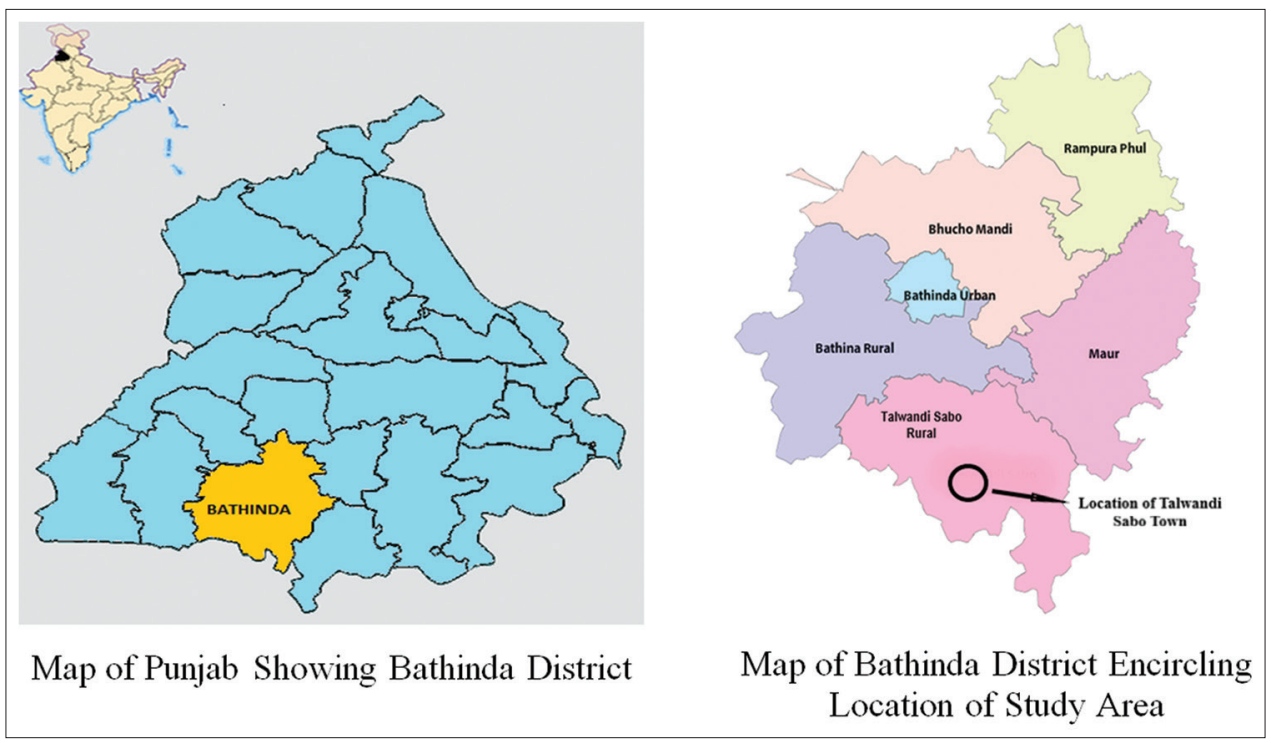

Figure 1: Geographical location of Study area 
habits, administration and treatment of different diseases. The demographic data was also analyzed to know the relationship of traditional knowledge with age, gender, education and occupation.

\section{Statistical Analysis}

The data was analyzed statistically by calculating informant consensus factor, fidelity level and frequency of citation.

\section{Informant Consensus Factor (ICF)}

Informant consensus factor for different ailment categories was calculated by using this formula [8].

$$
I C F=N u r-\frac{N t}{(N u r-1)}
$$

Where Nur $=$ Number of use report in a particular disease category and $\mathrm{Nt}=$ number of taxa used to treat that particular disease by the informants.

The ICF provide a range of 0-1, where high value (close to 1 ) of ICF for a given disease means only one or few plant species are used by large number of informants to treat that particular disease. On the other hand, low ICF value (close to 0 ) indicates that informants are disagree over the use of plant species to cure any particular disease. This may be due to random choosing or lack of communication among the informants. It means the information is not uniform.

\section{Fidelity Level (FL)}

Fidelity level was calculated to determine the most frequently used plant species for treating a particular ailment by the local people of the study area [9]. The fidelity level of each species for a particular disease has been calculated by using following formula:

$$
F L(\%)=\frac{N p}{N} \times 100
$$

Where $\mathrm{N}_{\mathrm{p}}$ is the number of informants who cited a given plant species for the treatment of particular ailment and $\mathrm{N}$ is number of informants that use the given plant species for all diseases.

\section{Frequency of Citation}

The frequency of citation of a particular species is calculated as follow:

$$
\begin{aligned}
& \text { Frequency of citation }(\%)= \\
& \frac{\text { Number of inf ormants whocited the species }}{\text { Totalnumber of inf ormants interviewed }} \times 100
\end{aligned}
$$

\section{RESULTS AND DISCUSSION}

\section{Demographic Data of the Informants}

The present study deals with documentation of medicinal plants and their associated traditional knowledge used by natives of
Talwandi Sabo. During the investigation, the information was collected from 25 respondents in which $80 \%$ were men and $20 \%$ women. The age varies from $22-75$ years from which $16 \%$ respondents were $>35$ age group, $40 \%$ respondent were between 36-50 years age group and 44\% were between 51-75 years. Based on their education it was found that most of the informants were above matriculation (44\%) followed by under metric $(36 \%)$ and matriculate (20\%). Occupation of informants included farmers (28\%), housewives (16\%), traditional healers $(40 \%)$ and others like students, drivers, workers etc. (16\%) (Table 1). After the observation and analysis, it was concluded that old age people have more knowledge about traditional medicines as compare to young age informants. The reason behind this differentiation is that old age people received this information from their fore fathers or their personal experience with plants as there were no synthetic drug at that time. It was observed that male members provided more information as compare to women. Male informants more than age group 51 years have more knowledge about plants. Similar observations were made during the ethnobotanical survey of medicinal plants in treatment of ticks in Vhembe District, Limpopo Province, South Africa [10]. These observations indicate that traditional knowledge is related to age and gender of an individual.

\section{Medicinal Plants and their Associated Traditional Knowledge}

A total of 88 plant species belonging to 77 genera and 42 families were used in traditional healthcare practices by the natives of study area. During survey, detailed information about traditional formulations like plants or plant parts used, local name of plants, habit, mode of preparation, mode of administration, etc. was documented (Table 2). Maximum number of plants of family Fabaceae (10) were used in traditional remedies followed by Solanaceae (6), Apiaceae, Myrtaceae, Lamiaceae (4 species each), Acanthaceae, Amaranthaceae, Amaryllidaceae (3 species each), etc. Treatment of about 60 major and minor ailments was done with these medicinal formulations. Herbs, shrubs, trees and climbers were the plant habits used for preparation of these remedies. From these, widely used plants were herbs (43.18\%)

Table 1: Demographic data of informants

\begin{tabular}{lcc}
\hline & Number & Percentage \\
\hline Gender & & \\
Male & 20 & 80 \\
Female & 5 & 20 \\
Total & 25 & 100 \\
Age & & \\
$<35$ & 4 & 16 \\
$36-50$ & 10 & 40 \\
$51-75$ & 11 & 44 \\
Education & & \\
Above Matriculation & 11 & 44 \\
Matriculation & 5 & 20 \\
$\quad$ Under Matriculation & 9 & 36 \\
Occupation & & \\
Farmer & 7 & 28 \\
Traditional healers & 10 & 40 \\
$\quad$ Housewives & 4 & 16 \\
Others (Drivers, Students, Worker) & 4 & 16 \\
\hline
\end{tabular}


Kaur, et al.

Table 2: Important medicinal plants used in traditional healthcare practices by the natives of selected area

\begin{tabular}{lllll}
\hline $\begin{array}{l}\text { Botanical Name } \\
\text { (Family) }\end{array}$ & $\begin{array}{l}\text { Local/Common } \\
\text { Name }\end{array}$ & Habit & Source & Uses \\
\hline Acacia nilotica L. & Kikar/Babul & Tree & Cultivated/ Wild & Twig is used as toothbrush to cure tooth problems and buds are eaten
\end{tabular}

to get rid from halitosis.

Fruit is a good fodder for cattle.

Flowers are used in the preparation of medicines for joint pain.

Bark is boiled in water and used as antiseptic.

Fruit in the form of pickle is used to increase male potency and also good for indigestion.

Decoction of fruits is used to cure bleeding gums.

Decoction of leaves is used to cure many eye problems and to

improve immunity.

Decoction of kikar and neem bark along with lahsun is prepared to

cure several ear problems.

It also cures many hair problems.

$\begin{array}{ll}\begin{array}{l}\text { Achyranthes aspera L. } \\ \text { (Amaranthaceae) }\end{array} & \begin{array}{l}\text { Puthkanda/Prickly } \\ \text { chaff flower }\end{array}\end{array}$

Aegle marmelos Correa. Bael/golden apple Tree

(Rutaceae)

Albizia lebbeck Benth. Shirish/lebbek tree Tree

(Fabaceae)

Allium cepa L.

(Amaryllidaceae)

Pyaaz/onion

Herb

Allium sativum $\mathrm{L}$

Lahsun/garlic

Herb

Cultivated

(Amaryllidaceae)

Aloe vera (L.) Burm. f. Kuwar gandal/aloe Herb (Xanthorrhoeaceae)

Argemone mexicana L. (Papavaraceae)

Satyanashi/Mexican Herb poppy

Wild

Cultivated

Azadirachta indica A. Neem/Indian lilac Tree Juss.

(Meliaceae)

Bauhinia variegata (L.). Kachnar/orchid tree Tree Benth.

(Fabaceae)
The ash of roots is mixed with honey and given orally to cure cough

Decoction of spiny seeds is also used to cure cough.

Mixture of Achyranthes and Tinospora stem powder is used to cure asthma.

Juice of fruit is best coolant and body tonic.

Fruit powder is a good mouth freshener.

Fruit juice is used to cure many liver disorders and is antidiabetic.

Cultivated/ Wild Paste of bark powder is applied dermally to cure skin disorders.

Leaves powder is taken with milk to get rid from back ache.

Extract of leaves mixed with rose petals extract (gulabjal) is used to cure eye problems.

Plant bulb used in vegetables as spices is good for gastro-intestinal problems.

Paste of bulb is applied dermally to cure many skin disorders.

Bulb extract is used as antiemetic.

Juice of pyaz along with hing powder is used to cure asthma and T.B. Raw bulblets are taken orally in empty stomach is said to be effective to treat Atherosclerosis disease.

Lahsun eaten in morning cures heart problems.

Bulblets along with Calotropis procera leaves are fried in mustard oil and oil is dropped in the ear for relieving earache.

It is also used to control uric acid and rheumatic pain.

Paste of black soil and garlic extract is applied dermally on aching teeth.

In the form of vegetable aloe is used for treatment of rheumatism, arthritis and as antidiabetic.

Gel is commonly used in preparation of many cosmetic products. Juice of aloe is a good body tonic and also controls diabetes and obesity.

Gel powder is used to cure many stomach problems, liver problems and menstrual problems.

Leaf powder is used to cure many eye problems.

Leaves extract is applied dermally to cure skin problems and wound healing.

Roots powder is used as blood purifier and during pregnancy, it is used to expand uterus.

Seeds powder is taken orally to control diabetes.

Seeds powder is also taken orally to cure joint pain.

Fruit paste is applied dermally to cure skin disorders.

Leaves boiled in water used as antiseptic and astringent.

Bark in powdered form is also applied dermally to cure skin problems.

Decoction of leaves is taken orally as it is antidiabetic.

Leaves of neem along with fatkadi, boiled in water and used

externally to cure skin problems.

Fruit paste is also antiseptic, antiallergic and anti-poisonous.

Decoction of leaves is used to cure ulcers.

Twig is used as toothbrush.

Leaf decoction is also a good blood purifier and used to remove stomach worms.

Cultivated Leaves of Bauhinia and Calotropis cure kidney problems.

Leaves are also used to cure tumor. 
Table 2: (Continued)

\begin{tabular}{lllll}
\hline $\begin{array}{l}\text { Botanical Name } \\
\text { (Family) }\end{array}$ & $\begin{array}{l}\text { Local/ Common } \\
\text { Name }\end{array}$ & Habit & Source & Uses \\
\hline Boerhavia diffusa L. & Punarnava/Itsit/red & Creeping herb Wild & Leaves extract is used in the preparation of medicines for eye problems.
\end{tabular}

nom. cons. spiderling

(Nyctaginaceae)

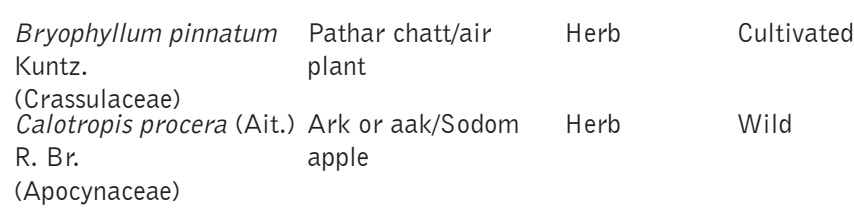

Cannabis sativa L. Bhang/hemp Herb Wild

(Cannabaceae)

\begin{tabular}{|c|c|c|c|}
\hline $\begin{array}{l}\text { Capparis decidua } \\
\text { (Forssk.) Edgew. } \\
\text { (Capparaceae) }\end{array}$ & Karir/Caper berry & Shrub & Wild \\
\hline $\begin{array}{l}\text { Carica papaya L. } \\
\text { (Caricaceae) }\end{array}$ & Papita/papaya & Small Tree & Cultivated \\
\hline $\begin{array}{l}\text { Casuarina equisetifolia L. } \\
\text { (Casuarinaceae) }\end{array}$ & Whistling Pine & Tree & Cultivated \\
\hline $\begin{array}{l}\text { Catharanthus roseus } \\
\text { (L.) G. Don }\end{array}$ & Sadabhar/periwinkle & Shrub & Ornamental \\
\hline $\begin{array}{l}\text { (Apocynaceae) } \\
\text { Citrullus colocynthis } \\
\text { (L.) Schrad. } \\
\text { (Cucurbitaceae) }\end{array}$ & $\begin{array}{l}\text { Kaur tuma/bitter } \\
\text { apple }\end{array}$ & Creeping herb & Wild \\
\hline
\end{tabular}

Decoction of leaves is taken orally as it has antibiotic properties and also used to cure swelling of stomach.

Paste of stem powder is applied dermally on burnt skin.

Decoction prepared from plant is used to cure urine problems.

Decoction of stem also have antianemic properties.

It is also used to cure many respiratory problems and rejuvenate the body. It has diuretic properties; therefore, raw leaves are eaten to remove kidney stone.

Plant leaves fried in mustard oil is used to cure skin problems. Fruits are used to cure fever.

Milky exudate is applied dermally to cure skin problems.

Leaf of plant is heated in mustard oil and applied dermally to cure skin problems.

Milk of flower bud is used to cure fever, cold and cough.

Mixture of ash of Swamp deer antler and Calotropis plant is used as antibiotic.

Pouring mustard oil in roots of Calotropis for 3 days is said to be effective against Jaundice.

Leaves of Calotropis are kept in shoes and wearing that shoes for 7 days is effective to control uric acid.

Leaves in purified form is used in preparation of medicines of cough. Leaves have antimalarial properties.

Whole plant in purified form (qwath/chooran) is used to cure blood clots. Plant milk or flower bud mixed with jaggery is used to cure fever.

Fine paste of leaves is applied dermally to treat joint pain.

Sand from roots of plant is tied on back to cure the backache.

Roots in powdered form is used to cure fever.

Powdered form of Almond, Anacardium occidentale (Cashew) Apium (Celery), Piper nigrum (Black pepper), Chrysopogon zizanioides

(Vetiver) is mixed with Cannabis leaves extract and taken orally to control Blood pressure.

Leaves are used to cure diseases of nervous system.

Leaves are narcotic, sedative and antidepressant.

Small dose of leaves act as appetizer and give relaxation to body. Leaves fried in ghee and extraction is applied externally on palms which induce sleep.

Seed oil is anticancerous.

Leaves along with jaggery and ghee applied dermally on mumps. Leaves are used to make medicines for urine problems and have analgesic property.

Leaves extract is used to cure ear problems.

A drink prepared by grinding Cannabis leaves, Almond and Khas Khas and then mixed in milk have cooling effect.

Fruit in form of pickle is used for indigestion and remove worms from stomach.

Powder of roasted root is taken with butter cure joint pain.

Raw fruits are eaten for their antibiotic property.

Leaves are eaten raw to cure dengu.

Raw fruit is eaten to get rid from kidney stones.

Fruit is also good for heart problems.

Leaves are burned on fire and smoke is taken to cure smallpox.

Leaves also have antibacterial properties.

Leaves are commonly used in the preparation of medicines for pain killer.

It also has antidiabetic and anticancer properties.

Powder of ajwain seeds along with fruit of kaur tuma is used for cattle diseases.

Fruit powdered is used as antidiabetic.

Powder of dry burnt fruit along with 4 kinds of salt and ajwain seeds is good for indigestion.

Fruit powder mixed with salt and lemon juice is also good for indigestion in human as well as animals.

Fruit powder is used to cure stomach pain, indigestion and constipation. Fruit along with haldi rhizome is packed in cotton cloth and boiled in water. Then grind to fine powder which is used to cure asthma.

Roots of kaur tuma is used to cure tumor.

Fruit powder is said to be effective to cure piles. 
Kaur, et al.

Table 2: (Continued)

\begin{tabular}{|c|c|c|c|c|}
\hline $\begin{array}{l}\text { Botanical Name } \\
\text { (Family) }\end{array}$ & $\begin{array}{l}\text { Local/ Common } \\
\text { Name }\end{array}$ & Habit & Source & Uses \\
\hline $\begin{array}{l}\text { Citrus limon (L.) } \\
\text { Burm. f. } \\
\text { (Rutaceae) }\end{array}$ & Nimbu/lemon & $\begin{array}{l}\text { Shrub or } \\
\text { small tree }\end{array}$ & Cultivated & $\begin{array}{l}\text { Fruit juice is used for indigestion, cures obesity, infection and act as } \\
\text { appetizer. } \\
\text { To cure fever, tea is prepared by adding juice of fruit without adding milk. }\end{array}$ \\
\hline
\end{tabular}

Fruit juice is antitoxic, anti-poisonous, antimalarial and have coolant effect.

In water, add lemon juice without adding sugar is good for RBCs enhancement.

Fruit juice is applied dermally on hairs to get rid of dandruff.

Fruit juice mixed with honey is used as mouth freshener.

Bark powder or fruit juice is used to cure kidney problems.

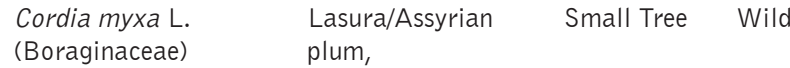

Curcuma longa L. (Zingiberaceae)
Herb

Cultivated

Juice along with honey is used to loss body weight.

Buds are eaten to cure swelling.

Seeds are used to cure mouth ulcers.

Fruit are used in pickle form that are analgesic and also have coolant effect.

Haldi powder mixed in mustard oil is applied externally on wounds. Haldi powder is orally taken with milk is analgesic, cure internal injury and stomach infection.

Kaur tuma fruit cut into two pieces and Turmeric rhizome is kept in between the fruit pieces just like sandwich and kept as such for 4 days. After this grind them and mixed with purified butter and applied on face to get rid of pimples, hyperpigmentation, dark circle etc. It is used to treat arthritis and used in many cosmetics. It also has an antibiotic, antiseptic and anticancerous properties. Ambhaldi in powdered form is along with ghee and milk is taken to cure internal injury.

Roasted wheat flour is mixed with haldi powder and taken orally for back ache.

Haldi powder is also used to lose weight and for rheumatism.

Paste of Haldi is applied externally on face to get rid of blemishes, blackhead, pimple, dark circle etc.

Haldi powder is also given to an infant to increase his appetite.

Stem fried in mustard oil is used to cure nail problems.

Cuscuta stem and Datura fruits are fried in oil and this oil is used for rheumatism.

Leaves are generally narcotic but if limited amount is given to cattle, it helps to enhance lactation.

Datura fruit and stem of Cuscuta are fried in mustard oil and this oil is applied on affected parts to get relieve from rheumatic pain.

Leaves of Datura, Vitex negundo and Ricinus communis are taken and oil is prepared which is used for pain or swelling.

Seeds are sedative.

Flowers are crushed to fine paste used for rheumatism.

Leaves are fried and fine paste is prepared for joint pain.

Leaves extract is affective for hair growth.

Leaves are fried in mustard oil and tied on painful joints.

Smoke of flower is taken to cure asthma.

Eclipta prostrata (L.) L. Bhringraj/false daisy Herb

Wild

Ficus benghalensis L. Bargad,Bohar/ Tree

(Moraceae) banyan

Wild/ Cultivated

Leaves are boiled in water and used as brain tonic.

Plant extract is used for hair problems.

Milky exudate is used to cure asthma, as a body tonic and also help

to increase immunity.

Milk is applied dermally for many skin problems.

Fruit milk is affective in increasing sperm count in men.

Milk of tree is also a good body tonic.

Leaf extract is used in treatment of hair problems.

Milk along with mustard oil used in treatment of ear pain.

Roots boiled in water is used in herbal medicines against cough.

Ficus religiosa L. Peepal/sacred fig Tree

Wild/ Cultivated

(Moraceae)

Leaves extract and fruits are taken as body tonic.

Bark in powdered form is used as painkiller against pain in kidney.

Powder of aerial roots of peepal is given to women to enhance

chances of pregnancy.

Leaves are used to cure heart blockage and other heart problems.

Raw fruit are eaten to enhance appetite.

Leaves extract is applied on snake bite.

Bark of peepal and neem in powdered form is used to cure kidney problems.

Decoction of leaves and bark is used to cure small pox and fever. 
Table 2: (Continued)

\begin{tabular}{|c|c|c|c|}
\hline $\begin{array}{l}\text { Botanical Name } \\
\text { (Family) }\end{array}$ & $\begin{array}{l}\text { Local/ Common } \\
\text { Name }\end{array}$ & Habit & Source \\
\hline $\begin{array}{l}\text { Justicia adhatoda L. } \\
\text { (Acanthcaeae) }\end{array}$ & $\begin{array}{l}\text { Vasaka, Bansa/ } \\
\text { Malabar nut }\end{array}$ & Shrub & Wild \\
\hline $\begin{array}{l}\text { Lepidium sativum L. } \\
\text { (Brassicaceae) }\end{array}$ & Halon/garden cress & Herb & Cultivated \\
\hline $\begin{array}{l}\text { Mentha arvensis L. } \\
\text { (Lamiaceae) }\end{array}$ & Pudina/mint & Herb & Cultivated \\
\hline $\begin{array}{l}\text { Momordica dioica Roxb. } \\
\text { ex Willd. } \\
\text { (Cucurbitaceae) }\end{array}$ & $\begin{array}{l}\text { Jhad karela/spiny } \\
\text { gourd }\end{array}$ & Climber & Wild \\
\hline $\begin{array}{l}\text { Moringa oleifera Lamk. } \\
\text { (Moringaceae) }\end{array}$ & $\begin{array}{l}\text { Suhanjana/ } \\
\text { drumstick tree }\end{array}$ & Tree & Cultivated \\
\hline $\begin{array}{l}\text { Ocimum sanctum L. } \\
\text { (Lamiaceae) }\end{array}$ & Tulsi/holy basil & Herb & Cultivated \\
\hline
\end{tabular}

Papaver somniferum L. Afeem/opium poppy Herb (Papaveraceae)

$\begin{array}{llll}\begin{array}{l}\text { Phyllanthus emblica L. } \\ \text { (Phyllanthaceae) }\end{array} & \begin{array}{l}\text { Amla/Indian } \\ \text { gooseberry }\end{array} & \text { Tree } & \text { Cultivated }\end{array}$

Cultivated (Phyllanthaceae) flower

$\begin{array}{llll}\begin{array}{l}\text { Piper nigrum L. } \\ \text { (Piperaceae) }\end{array} & \begin{array}{l}\text { Kali mirch/black } \\ \text { pepper }\end{array} & \text { Climbing vine } & \text { Market } \\ \begin{array}{l}\text { Prosopis cineraria (L.) } \\ \text { Druce }\end{array} & \text { Jhandi/screw-bean } & \text { Tree } & \text { Wild/ Cultivated }\end{array}$

(Fabaceae) (Myrtaceae)

Amrood/guava

Tree

Punica granatum L. (Lythraceae)

Anaar/pome-granate Shrub
Cultivated

Wild/ Market

Fruit in powdered form is used to cure liver problems.

Also used in herbal medicines to treat jaundice, intestinal infection, diabetes, and loss of appetite.

Fruit powder is best against indigestion.

Fruit boiled in tea act as stimulant and cure cough, cold, fever etc. Fruit is used in preparation of rayta because of its cooling effect. Powdered form or decoction of roots is used to cure liver problems.

Pickle prepared from fruit is good for indigestion.

Leaf powder or extract is used to cure diarrhea.

Powder of leaf along with black salt is affective against rheumatism.

Raw fruit or its juice is taken orally as blood purifier, indigestion, anti-anemic and as body tonic.

Peel of fruit taken orally in powdered form is used to cure loose motion.

Paste of leaf is applied on face to get rid of skin problems

Paste of young leaves has diuretic property and cures many abdominal problems.

Seeds boiled in water used for skin dryness.

Leaves given to cattle to enhance lactation.

Oil extracted from seeds is used for rheumatism.

Purified seed oil is taken with milk as laxative.

Fruit also have laxative properties.

Leaves boiled in water is used for joint pain.

Extracted oil is also used for many stomach problems and breast problems.

Leaves are tied externally for rheumatism. 
Kaur, et al.

Table 2: (Continued)

\begin{tabular}{|c|c|c|c|}
\hline $\begin{array}{l}\text { Botanical Name } \\
\text { (Family) }\end{array}$ & $\begin{array}{l}\text { Local/ Common } \\
\text { Name }\end{array}$ & Habit & Source \\
\hline $\begin{array}{l}\text { Rosa indica L. } \\
\text { (Rosaceae) }\end{array}$ & Gulaab/rose & Shrub & Cultivated \\
\hline $\begin{array}{l}\text { Saccharum } \\
\text { officinarum L. } \\
\text { (Poaceae) }\end{array}$ & Ganna/sugarcane & Herb & Cultivated \\
\hline $\begin{array}{l}\text { Saraca asoca (Roxb.) } \\
\text { Willd. } \\
\text { (Fabaceae) }\end{array}$ & Ashoka tree & Tree & Cultivated \\
\hline $\begin{array}{l}\text { Simarouba glauca DC. } \\
\text { (Simaroubaceae) }\end{array}$ & $\begin{array}{l}\text { Lakshmi taru/ } \\
\text { paradise-tree }\end{array}$ & Tree & Market \\
\hline $\begin{array}{l}\text { Solanum nigrum L. } \\
\text { (Solanaceae) }\end{array}$ & $\begin{array}{l}\text { Peelan/Black } \\
\text { Nightshade }\end{array}$ & Herb & Wild \\
\hline $\begin{array}{l}\text { Solanum virginianum L. } \\
\text { (Solanaceae) }\end{array}$ & $\begin{array}{l}\text { Samak-namoli/ } \\
\text { yellow-fruit } \\
\text { nightshade }\end{array}$ & Herb & Wild \\
\hline
\end{tabular}

\section{Spilanthes acmella}

(L.) L.

(Acanthaceae)

Syzygium cumini (L.)

Skeels.

(Myrtaceae)

\section{Terminalia arjuna
(Roxb.) Wight. and Arn.
(Combretaceae)}

Terminalia bellirica

Retz.

(Combretaceae)

Terminalia chebula

Retz.

(Combretaceae)

Tinospora cordifolia

Willd.

(Menispermaceae)

Trachyspermum ammi

L.

(Apiaceae)

Tribulus terrestris L. (Zygophyllaceae)
Akarkara/toothache Herb plant

Jamun/black plum Tree

Arjun tree

Bahera

Harar/chebulic myrobalan

Giloy/heart-leaved Climber moonseed

Ajwain/ajowan caraway

Herb

Cultivated

Bakhra/devil's-thorn Herb

Wild
Uses

Powder of dried petals are used to cure menstrual problems.

Because of its cooling effect, extract is used in preparation of many cosmetic products.

Paste of Rose petal with sugar locally called 'Gulkand' is used as coolant.

Juice extracted from stem cure jaundice and have coolant effect. 2- 3 drops of Desi liquor prepare from sugarcane put in ear to get relieve from earache.

Tonic prepared from ashoka is used for removal of kidney stone, menstrual problems and other gynaecological problems.

Leaves powder or decoction is used against liver problems.

Leaves are used to treat fever, malaria and as body tonic.

Fruit eaten raw is used to cure jaundice.

Extract of fruit is used to cure back pain.

Vegetable prepared from whole plant is also good for body pain. Vegetable of leaves is eaten to control diabetes.

Plant burnt on fire and smoke is taken through nose cures Epilepsy. Fruits fried in mustard oil applied externally on wounds.

Smoke of burnt fruit is used to vanish tooth worms.

Fruits powder and some bulblets of garlic are fried in mustard oil and this oil is applied dermally for many skin problems.

Fruit roasted on fire and smoke is taken to cure asthma.

Plant is also used for purification of medicines in Ayurveda.

Wild/ Market Decoction of whole plant cure jaundice and many sexual disorders.

Decoction is also considered as good body tonic.

Flowers are applied on aching teeth.

Cultivated/ Wild Seeds powder is used as antidiabetic.

Leaves chewed raw is used to cure mouth ulcers.

Powder of Jamun seeds and Mango leaves are also used to control diabetes.

Roasted seeds powder is used to control hiccups.

Decoction prepared from bark is used against heart diseases.

Bark powder is mixed with water and milk in equal amount cure

hypertension and control B.P.

Fruit powder is effective against stomach problems such as gas in stomach.

It also has laxative properties.

It is also good for rejuvenation.

Fruit powder is good for indigestion.

Fruit powder of Harar and Bahera is good for eyes.

Fruit powder mixed with Lemon juice is used for tooth problems.

Mixture of Harar, Bahera and Amla called 'Triphla Churan' is best

for rejuvenation.

Decoction of stem is used against cough, cold, dengu, flu, fever,

malaria and typhoid.

It also has antibiotic properties.

Decoction is also good for curing kala azaar, indigestion and good for RBCs enhancement.

It is also used for many respiratory disorders.

Seeds of ajwain along with 4 kinds of salt is used to cure stomach ache. Ajwain seeds along with saunf boiled in water is used for stomach ache.

Fruit powder is used to cure cough.

Paste of Ajwain seeds and garlic bulblets in mustard oil is applied dermally for chikungunia.

Fruit is used to cure gynaecological problems like leukorrhea.

Fruits of pakhra and seeds of ajwain are roasted on medium fire and ground to form powder which is used for indigestion in animals. Fruits also have diuretic and antibiotic properties.

Dried fruits are fried in desi ghee are used to relieve back ache. Fruit powder is used to remove kidney stone through micturition. Powdered form of fruit is taken orally with water for joint pain. Seeds in powdered form are also good for back ache.

Fruit crushed in paste form applied dermally on joints to get relief from pain.

Fruit is also used against cough and cold. 
Table 2: (Continued)

\begin{tabular}{|c|c|c|c|c|}
\hline $\begin{array}{l}\text { Botanical Name } \\
\text { (Family) }\end{array}$ & $\begin{array}{l}\text { Local/ Common } \\
\text { Name }\end{array}$ & Habit & Source & Uses \\
\hline $\begin{array}{l}\text { Triticum aestivum L. } \\
\text { (Poaceae) }\end{array}$ & Kanak/wheat & Herb & Cultivated & $\begin{array}{l}\text { Decoction of young plant or leaves have digestive and anticancerous } \\
\text { properties. } \\
\text { Crushed seeds are boiled in water or milk with other ingredients } \\
\text { (Dalia) is a good body tonic for human as well as animals. }\end{array}$ \\
\hline $\begin{array}{l}\text { Tylophora indica R. Br. } \\
\text { (Apocynaceae) }\end{array}$ & $\begin{array}{l}\text { Anantmul/Indian } \\
\text { Ipecac }\end{array}$ & Climber & Market & $\begin{array}{l}\text { To cure urine problems, roots of plant are used in powdered form. } \\
\text { Plant is also used for the treatment of asthma and diarrhea. }\end{array}$ \\
\hline $\begin{array}{l}\text { Vitex negundo L. } \\
\text { (Lamiaceae) }\end{array}$ & $\begin{array}{l}\text { Sambhalu or } \\
\text { Nirgundi/ five-leaved } \\
\text { chaste tree }\end{array}$ & Tree & Wild & $\begin{array}{l}\text { Leaves boiled in water is used for many skin problems. } \\
\text { Plant is also used to cure arthritis. } \\
\text { Oil extracted from leaf is a good pain killer and cure ear problems. }\end{array}$ \\
\hline $\begin{array}{l}\text { Withania somnifera } \\
\text { Dunal. } \\
\text { (Solanaceae) }\end{array}$ & $\begin{array}{l}\text { Ashwa-gandha/ } \\
\text { Indian ginseng }\end{array}$ & Herb & Wild & $\begin{array}{l}\text { To cure old cough (kali khansi), Ashwagandha and Achyranthes } \\
\text { aspera powder are mixed and given orally. } \\
\text { It is also a good body tonic. } \\
\text { Leaves boiled in tea are best for cough and cold. } \\
\text { It is also a good painkiller and increases male potency. } \\
\text { Roots powder or decoction is a good body and brain tonic. } \\
\text { It also reduces inflammation. } \\
\text { Plant powder is taken with milk to increase height. } \\
\text { Stem powder taken with milk is good for back pain and weakness. } \\
\text { It is also taken orally to cure many sexual disorders. }\end{array}$ \\
\hline $\begin{array}{l}\text { Zingiber officinale } \\
\text { Roscoe } \\
\text { (Zingiberaceae) }\end{array}$ & Adrak/ ginger & Herb & Cultivated & $\begin{array}{l}\text { Extract of adrak, garlic along with honey cure cough. } \\
\text { Piece of rhizome boiled in tea is good for flu, headache, cough and cold. } \\
\text { It also cures vomiting. } \\
\text { Extract of adrak fight against weak immunity. } \\
\text { It also has thermoregulatory property. }\end{array}$ \\
\hline
\end{tabular}

followed by trees $(35.22 \%)$, shrubs $(11.36 \%)$, climbers $(9.09 \%)$ and creepers $(1.13 \%)$.

Commonly each plant part is used in the preparation of medicines, but most frequently used plant part is leaf (34.16\%). Other plant parts are fruits $(29.16 \%)$, roots $(10.83 \%)$, stem $(5.83 \%)$, flower $(1.66 \%)$, twig (1.66\%) etc. (Figure 2$)$. In traditional medicines, leaves and herbs are used more often because of their common availability (leaves available throughout the year) and formulations are easier to prepare (as they are soft). According to informants, leaves are highly effective in cure of various ailments. Therefore, scientific evaluation or phytochemical screening of leaves of medicinal plants should be preferred in place of other plant parts.

Most of the plant species used by local people were cultivated and some were purchased from the market. But traditional healers mainly collected the wild herbs for the preparation of medicinal formulations. Unfortunately, that wild herbs are eliminating from the study area due to increasing urbanization and improved agricultural practices. The mode of preparation of these medicines was in powder, paste, decoction and extract form. Natives commonly used these household remedies to cure the small ailments like fever, cough, cold, wounds, indigestion, infection, inflammation etc. The most common mode of administration is oral and it may be taken in the form of powder or decoction. Some of the remedies were applied dermally to cure the skin problems. Maximum number of plant species were used to cure gastro-intestinal diseases \& skin diseases (32 each) followed by respiratory diseases (22), skeletomuscular diseases (20) and dental problems (15) (Figure 3).

Some plants were used in the preparation of medicines to cure cancer such as seeds of Cannabis sativa, rhizome of Curcuma longa, fruit of Momordica dioica and seedlings of Triticum

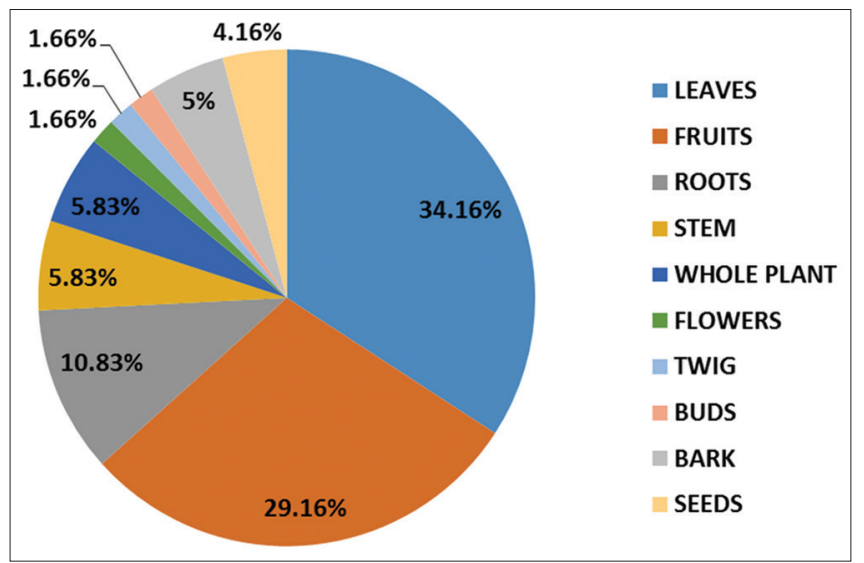

Figure 2: Plant parts used in traditional formulations

aestivum. Seeds powder of Abrus precatorius was used to abort child. Decoction of Kal megh (Andrographis paniculata) was used to cure liver disorders like jaundice. Eating murabba of bamboo shoots (Bambusa vulgaris) in empty stomach was used as herbal remedy for increasing height. Plant powder of Crinum latifolium (Sudarshan) is used to cure fever. Leaf extract is also used for earache. Fruits of Ashoka (Polyalthia longifolia) are used in preparation of medicines for RBCs enhancement. Seeds of kala datura are used as good antidepressant and to cure paralysis. According to respondents, the formulation is prepared by the mixture of two or more plant species are more effective than a single plant. For example, the combination of Achyranthes and Tinospora in powdered form is used to cure Asthma. These plant species were also used singly to control the disease.

During survey it was observed that traditional healers learn these practices from their ancestors. They are now further trying to pass this knowledge to their next generations. But young generation is 


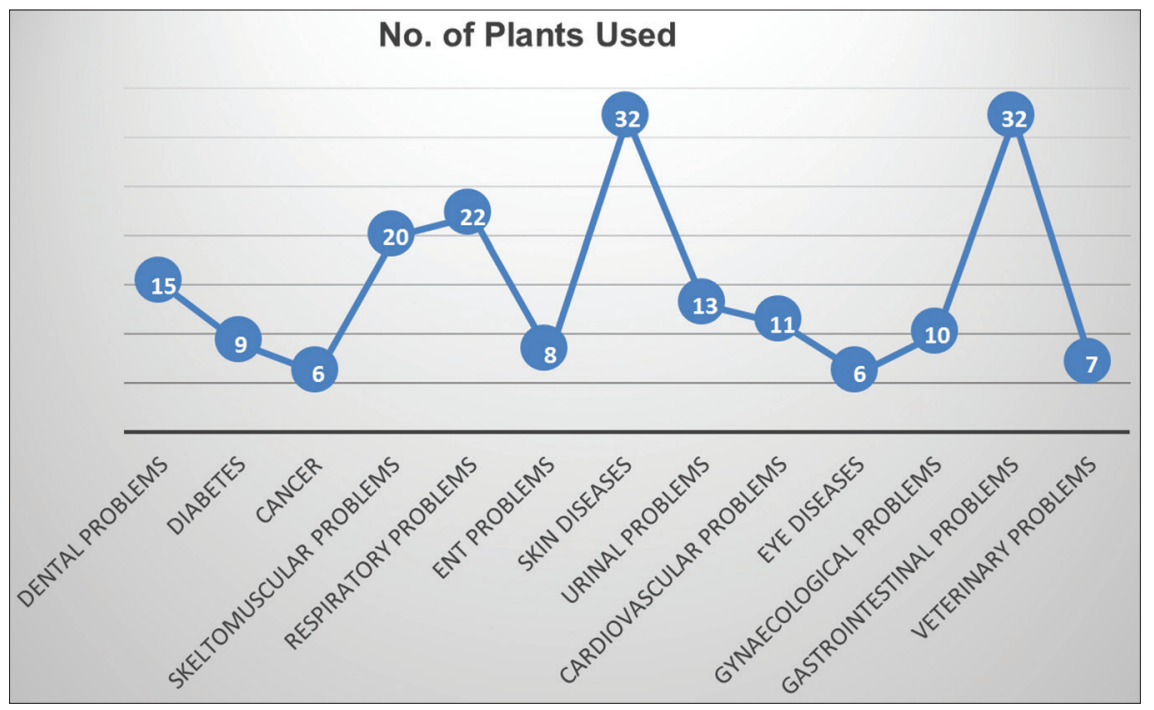

Figure 3: Different diseases cured by medicinal plants

Table 3: Informant Consensus Factor (ICF) of major diseases

\begin{tabular}{lccc}
\hline Major Diseases & $\begin{array}{c}\text { No. of use report } \\
\text { (Nur) }\end{array}$ & $\begin{array}{c}\text { No. of taxa } \\
\text { (Nt) }\end{array}$ & ICF \\
\hline Dental problems & 44 & 15 & 0.67 \\
Diabetes & 34 & 9 & 0.75 \\
Cancer & 7 & 6 & 0.16 \\
Ophthalmological diseases & 10 & 6 & 0.44 \\
ENT & 16 & 8 & 0.53 \\
Skeletomuscular diseases & 50 & 20 & 0.61 \\
Respiratory problems & 117 & 22 & 0.81 \\
Gastrointestinal problems & 116 & 32 & 0.73 \\
Skin diseases & 92 & 32 & 0.65 \\
Urinary problems & 23 & 13 & 0.45 \\
Gynecological problems & 13 & 10 & 0.25 \\
Mental problems & 24 & 8 & 0.69 \\
Cardiovascular problems & 23 & 11 & 0.54 \\
Veterinary problems & 8 & 7 & 0.14 \\
\hline
\end{tabular}

not taking much interest in traditional practices. Similar results were recorded in Hoshiarpur District of Punjab, India [11]. More problems related to extinction of this knowledge is due to nonavailability of plants and if available those were tough to identify. Natives of study area have opinion that synthetic medicines are very expensive and had many side effects on health. According to the informants, traditional medicines are affordable, effective and secure as compare to allopathic medicines. They also believe that, the traditional medicines derived from medicinal plants are time taking but eliminate the root cause of the disease. Therefore, most people of this area generally prefer to use household remedies or herbal medicines. Further they believe that these remedies were easy to prepare and self-administrated. Similar observations were made during the survey of plants from Neelum, Azad Jammu \& Kashmir, Pakistan [12].

\section{Statistical Data Analysis}

\section{Informant consensus factor (ICF)}

For testing the homogeneity in informant's knowledge, informant consensus factor for the common health problems
Table 4: Fidelity level of some medicinal plants used against a particular disease

\begin{tabular}{llccc}
\hline Ailments & Plant Name & Np & N & $\begin{array}{c}\text { Fidelity } \\
\text { level (\%) }\end{array}$ \\
\hline Diabetes & Momordica dioica & 17 & 20 & 85 \\
Skin diseases & Syzygium cumini & 20 & 21 & 95.2 \\
& Azadirachta indica & 19 & 21 & 90.4 \\
& Aloe vera & 25 & 25 & 100 \\
Respiratory diseases & Curcuma longa & 17 & 22 & 77.2 \\
& Ocimum sanctum & 17 & 21 & 80.9 \\
Gastro-intestinal problems & Cingiber officinale & 13 & 13 & 100 \\
& Citrullus colocynthis & 18 & 20 & 90 \\
& Phyllanthus emblica & 15 & 20 & 75 \\
Dental problems & Citrus limon & 14 & 17 & 82.3 \\
& Syzygium aromaticum & 14 & 14 & 100 \\
& Acacia nilotica & 11 & 17 & 64.7 \\
Cardiovascular diseases & Azadirachta indica & 15 & 21 & 71.4 \\
& Terminalia arjuna & 8 & 8 & 100 \\
Fever & Punica granatum & 5 & 8 & 62.5 \\
Mental Disorders & Tinospora cordifolia & 17 & 20 & 85 \\
Cancer & Convolvulus pluricaulis & 17 & 17 & 100 \\
& Triticum aestivum & 3 & 4 & 75 \\
Skeletomuscular diseases & Cribulus terrestris & 4 & 15 & 26.6 \\
Veterinary diseases & Curcuma longa & 20 & 22 & 90.9 \\
& Citrullus colocynthis & 12 & 20 & 60 \\
\hline
\end{tabular}

of area was calculated. Based on the information collected from informants, the ailments were grouped into different disease categories. The value of ICF could be useful in practicing the medicinal plants for the further scientific research. The ICF value mainly ranges from $0.01-1.00$. The results show that the value of ICF calculations in the study area ranges from 0.14 to 0.81 (Table-3). Respiratory problems have the highest ICF value $(0.81)$ with 117 use reports for 22 plant species. Further it is followed by Diabetes (0.75), Gastro-intestinal problems (0.73), mental problems (0.69), Skin diseases (0.65) and skeletomuscular diseases (0.61). Mussarat and co-researchers documented the ethno-medicinal knowledge of people living around Indus River. They observed the highest ICF value (0.80) for gastrointestinal and kidney problems followed by 
Table 5: Frequency of citation of some important medicinal plants

\begin{tabular}{lccclccc}
\hline Plant Name & Np & N & Frequency of citation (\%age) & Plant Name & Np & N & Frequency of citation (\%age) \\
\hline Abrus precatorius & 1 & 25 & 4 & Justicia adhatoda & 11 & 25 & 44 \\
Acacia nilotica & 17 & 25 & 68 & Mentha arvensis & 20 & 25 & 25 \\
Achyranthes aspera & 8 & 25 & 32 & Momordica dioica & 21 & 25 & 80 \\
Aegle marmelos & 7 & 25 & 28 & Moringa oleifera & 5 & 25 & 84 \\
Aloe vera & 25 & 25 & 100 & Ocimum sanctum & 21 & 25 & 20 \\
Andrographis paniculata & 3 & 25 & 12 & Papaver somniferum & 1 & 25 & 84 \\
Azadirachta indica & 21 & 25 & 84 & Phyllanthus emblica & 20 & 25 & 4 \\
Bambusa vulgaris & 1 & 25 & 4 & Phyllanthus fraternus & 1 & 25 & 80 \\
Boerhavia diffusa & 12 & 25 & 48 & Solanum nigrum & 20 & 25 & 4 \\
Bryophyllum pinnatum & 10 & 25 & 40 & Solanum virginianum & 23 & 25 & 80 \\
Calotropis procera & 17 & 25 & 68 & Spilanthes acmella & 3 & 25 & 92 \\
Cannabis sativa & 17 & 25 & 68 & Syzygium cumini & 21 & 25 & 12 \\
Capparis deciduas & 6 & 25 & 24 & Terminalia arjuna & 8 & 25 & 84 \\
Casuarina equisetifolia & 1 & 25 & 4 & Tinospora cordifolia & 20 & 25 & 32 \\
Citrullus colocynthis & 20 & 25 & 80 & Tribulus terrestris & 15 & 25 & 80 \\
Citrus limon & 17 & 25 & 68 & Tylophora indica & 1 & 25 & 60 \\
Cocos nucifera & 16 & 25 & 64 & Vitex negundo & 16 & 25 & 4 \\
Curcuma longa & 22 & 25 & 88 & Withania somnifera & 13 & 25 & 64 \\
Datura innoxia & 11 & 25 & 44 & Zingiber officinale & 13 & 25 & 52 \\
Ficus religiosa & 12 & 25 & 48 & & & 52 \\
\hline
\end{tabular}

respiratory infections (0.72) and skin infections (0.73) [13]. The least ICF factor from the study area was of Cancer (0.16) and Veterinary problems (0.14). The high ICF Value of the diseases in study area conclude that these diseases are common in the area. This also mean that there is better communication between the informants for treating these ailment categories. The low ICF value means lack of information about the use of plant.

\section{Fidelity level (FL)}

The plant species with highest FL value is known to be the most preferred species for a particular ailment. The FL 100\% indicate that all the use report mentions the same plant species for the particular disease. In the present study, the FL of some important plants was calculated. These are the plant species which were preferred for treating 11 different ailments. Syzygium cumini has the highest FL value $(95.2 \%)$ for the diabetes. This means Syzygium cumini is the most common plant species known to natives of the area to control diabetes. So high fidelity level of Syzygium cumini indicates that the scientific study can be further done on this plant for making the better drug to cure the disease. The high-fidelity level of Momordica charantia (89.9\%) and Syzygium cumini $(82.2 \%)$ for diabetes was also recorded in Doaba region of Punjab [6]. The Fidelity level of Aloe vera for the cure of skin diseases is $100 \%$, that means the value of $(\mathrm{Np}, \mathrm{N})$ is $(25,25)$. Azadirachta indica has $(90.4 \%)$ fidelity level for the cure of skin diseases. The more plant species were also observed with $100 \%$ fidelity level for the particular ailments like syzygium aromaticum $(13,13)$ for dental use, Zingiber officinale for respiratory problems $(13,13)$, Terminalia arjuna for cardiovascular problems $(8,8)$, Convolvulus pluricaulis for mental disorders $(17,17)$. For cancer Triticum aestivum has the fidelity level of $(3,4)$. Curcuma longa had $90.9 \%$ fidelity level for skeletomuscular diseases. The least fidelity level means the lack of knowledge about the plant species for a particular disease such as for skeletomuscular diseases the plant used Tribulus terrestris has fidelity level $26.6 \%$ (Table- 4).

\section{Frequency of Citation}

The frequency of citation of some important medicinal plants reported from the study area has been calculated. Most frequently used medicinal plants are Aloe vera (100\%), Solanum virginianum (92\%), Curcuma longa (88\%), Momordica dioica, Syzygium cumini (84\%), Ricinus communis (76\%), Calotropis procera (72\%), Acacia nilotica, Cannabis sativa (68\%) Trachyspermum ammi (64\%). Some least cited species are Abrus precatorius, Tylophora indica, Eclipta prostrata, Bambusa vulgaris etc. (Table- 5 ).

\section{CONCLUSIONS}

Present survey for documentation of medicinal plants and their associated traditional knowledge was carried out in Talwandi Sabo town of district Bathinda, Punjab. This study reveals that even though the accessibility of modern medicines is available at door steps, many medicinal plants are still broadly used by the natives of study area, at least for the treatment of common ailments like cough, cold, fever, headache, body ache, indigestion, skin problems, dental problems etc. People believe that although these medicines are time consuming but eliminate the disease from roots. The plants with $100 \%$ fidelity level are known to be the most preferred species for a particular ailment. Therefore, scientific validation of these plants for their ethnomedicinal claim and their phytochemical screening can be utilized for the development of new and alternate drugs against a particular disease with due benefit sharing with the traditional knowledge holders. It is also worthwhile to mention that, this knowledge is only limited to traditional healers and elderly persons. Young generation has little interest in these practices which shows that traditional knowledge of medicinal plants is in severe danger of being lost. Therefore, the use of these medicinal 
plants should be kept safe in written form, so that this should be helpful in future also. In present investigation, some unique plants and traditional formulations have been reported which should be recorded in Traditional Knowledge Digital Library (TKDL) so that these medicinal plants and their associated traditional knowledge can be protect from biopiracy.

\section{ACKNOWLEDGEMENTS}

Authors are thankful to all the informants for providing valuable information related to traditional use of medicinal plants. We are also grateful to Akal University, Talwandi Sabo (Bathinda) for providing necessary facilities to carry out this research.

\section{AUTHOR'S CONTRIBUTIONS}

Kuljinder Kaur gathered information, analyzed data and wrote manuscript with support from Sweta Thakur; Amandeep Kaur contributed in collection and analysis of data.

\section{REFERENCES}

1. Duke JA, Martinez RV. Amazonian Ethnobotanical Dictionary. In: Handbook of Ethnobotanicals (Peru). Boca Raton, FL: CRC Press; 1994.

2. Cowan MM. Plant product as antimicrobial agents. Clinical Microbiology Reviews.1999;12(4): 564-582.
3. Shakya SR. Medicinal uses of ginger (Zingiber officinale Roscoe) improves growth and enhances immunity in aquaculture. International Journal of Chemical Studies. 2015; 3(2): 83-87.

4. Krief S, Martin MT, Grellier P, Kasenene J, Sevenet T. Novel antimalarial compounds isolated in a survey of self-medicative behavior of wild chimpanzees in Uganda. Antimicrobial Agents and Chemotherapy. 2004; 48(8): 3196-3199

5. Sidhu K, Kaur R. Maternal health care through medicinal plants Studies on Ethno-Medicine. 2007;1(2): 157-160.

6. Kaur K. Evaluation of angiosperm flora and use of traditional plant remedies in Doaba Region of Punjab. Ph.D. thesis in Botany to Punjab University, Chandigarh. 2014.

7. Singh A. Herbal Medicine: Dream Unresolved. Ethnobotanical Leaflets. 2007; 11: 195-198.

8. Rokaya MB, Munzbergova Z, Timsina B. Ethnomedicinal study of medicinal plants from the Humla district of western Nepal. Journal of Ethnopharmacology. 2010;130: 485-504.

9. Ugulu I. Traditional ethnobotanical knowledge about medicinal plants used for external therapies in Alasehir, Turkey. International Journal of Medicinal and Aromatic Plants. 2011;1(2): 101-106.

10. Magwede K, Tshisikhawe MP, Luseba D, Bhat RB. Ethnobotanical survey of medicinal plants used in treatment of ticks. Journal of Experimental Botany. 2014; 83: 155-165

11. Sidhu MC, Kaur K, Ahluwalia AS. The use of traditional plant remedies in Hoshiarpur District of Punjab, India. Journal of Phytology. 2011; 3(9): 10-19.

12. Mahmood A, Malik R, Shinwari Z, Mahmood A. Ethnobotanical survey of plants from Neelum, Azad Jammu \& Kashmir, Pakistan. Pakistan Journal of Botany. 2011; 43: 105-110.

13. Mussarat S, Salam NMA, Tariq A, Wazir SM, Ullah R, Adnan M. Uses of ethnomedicinal plants by the people living around Indus River Evidence- Based Complementary and Alternative Medicine, Article ID 212634, 2014; 14 pp. 